\title{
Demand for University Continuing Education in Canada: Who Participates and Why?
}

\author{
Maria Adamuti-Trache, University of British Columbia \\ Hans G. Schuetze, University of British Columbia
}

\section{Abstract}

The demand for and participation in continuing education by Canadian university graduates who completed bachelor and/or first professional degrees in 1995 are analyzed in this article. Within five years of completing their first degree, in addition to participating in graduate programs, a large number of those graduates participated in non-degree programs and courses for career and job purposes and for personal reasons. Through a descriptive analysis of National Graduate Survey (NGS) data for the 1995 cohort, the authors examined the socio-demographic profile of participants, their motives for participating in continuing education, and their choice of specific programs. According to the study findings, the respondents'
RÉSUMÉ

Cet article étudie la demande et la participation à l'éducation permanente par des diplômés universitaires au Canada qui ont terminé leurs études de premier cycle universitaire et/ou leurs grades légaux en 1995. Dans les cinq ans suivant leur premier diplôme, en plus de la participation à des programmes de deuxième cycle, un grand nombre de ces diplômés ont participé à des programmes et cours non accrédités pour des raisons de carrière et d'emploi et pour des raisons personnelles. À l'aide d'une analyse descriptive des données de l'Enquête nationale auprès des diplômés (END) pour la cohorte de 1995, les auteurs ont examiné le profil sociodémographique des participants à l'éducation permanente, et leur choix de programmes 
labour-market situation, both in objective and subjective terms, was an important reason for participating in continuing education; indeed, more than three-quarters of participants had a job/educationrelated reason for participating in continuing education. In particular, the study provides information and insight into the demand (expressed and latent) of a targeted university continuing education audience. The National Graduate Survey together with Adult Education and Training Survey (AETS) and institutional data, allow a more realistic assessment of participants' needs and program preferences. spécifiques. Les résultats ont indiqué que la situation des répondants sur le marché du travail, à la fois en termes objectifs et subjectifs, était une source importante de motivation; en effet, plus de trois quarts des répondants avaient une raison liée à l'emploi ou à l'éducation pour participer à l'éducation permanente. Plus particulièrement, les auteurs fournissent des renseignements quant à la demande (exprimée et latente) d'un auditoire ciblé en éducation permanente à l'université, ce qui, en conjonction avec les données de l'Enquête sur l'éducation et sur la formation des adultes (EÉFA) et de l'institution, a permis une évaluation plus réaliste des besoins des participants et des préférences de programme.

\section{INTRODUCTION}

In all industrialized countries, continuing education and training has become a common preoccupation of the workforce. According to the Organization for Economic Co-operation and Development (OECD, 2008), ${ }_{1}^{1}$ approximately one-quarter of 25- to 64-year-old adults in Canada participate in some form of non-formal, job-related continuing education and training. This situates Canada among the countries with a well-developed system of education and training by OECD standards, after Denmark, Finland, Sweden, the United States, Switzerland, and the United Kingdom.

However, it is fair to observe that Canada's adult learning system is not much of a "system," consisting as it does of a bewildering array of sponsors, including technical institutes, community colleges and universities, libraries, labour and religious organizations, community-based organizations, and commercial organizations and businesses (Bélanger \& Tuijnman, 1997), that are largely uncoordinated and partially in competition with each other. Although over the last few years the federal government and several of the provinces have initiated a number of new programs and mechanisms 
to serve a more-diverse adult population, provincial adult learning systems remain complex, fragmented, and incomplete (Myers \& de Broucker, 2006). It is not surprising, then, that those who take advantage of continuing education and training opportunities are mainly individuals who have prior experience accessing the system. The 2008 OECD report demonstrated that the greatest level of participation in non-formal continuing education was observed among those with higher levels of educational attainment. In Canada, the participation level is 35\% among adults with tertiary (postsecondary) education, $20 \%$ among those with an upper-secondary and a post-secondary non-tertiary education, and $6 \%$ among those with a lowersecondary education.

Since there is neither a legal nor any clear definition of the term "continuing education" (CE), terms such as further education, continuing studies, or adult education are often used interchangeably with continuing education. Adult education is probably the most encompassing of these terms, comprising vocational, social, recreational, and self-developmental dimensions (Selman, Cooke, Selman, \& Dampier, 1998). University continuing education (UCE) is a more-specific and better-defined term because the identity of the provider is unequivocal. In principle, it means all forms of continuing education offered by a university, including not only single courses or entire programs but also single events such as presentations, conferences, and workshops (Brooke \& Waldron, 1994; Rohfeld, 1990; Titmus, Knoll, \& Wittpoth, 1993). In most instances, however, UCE is used more narrowly to mean courses, programs, and other offerings delivered by special units within the university, called variably University Extension, Continuing Education, Continuing Studies, or something similar. Since UCE offerings can be either credit or non-credit, degree or non-degree (i.e., courses toward a second or third degree or non-credit-bearing learning programs or events such as workshops and seminars), embracing a broader view that describes participation in any educational program or single event at the post-secondary level, whether organized by central CE units or mainstream disciplinary departments, seems more realistic. Indeed, a broader definition of CE supports current trends toward a flexible provision of higher education (e.g., recognition of prior learning, credit transfer, articulated programs). This approach is also consistent with the need of learners to customize their educational pathways to accommodate careers and family life. Among learners, university graduates who have already demonstrated the skills necessary to engage with the system are likely to embrace a variety of formal education pathways (Adamuti-Trache, 2008).

The aim of this article is to analyze graduates' demand for, and participation in, continuing education in relation to their work and family situations. Specifically, the scope of the study is twofold: (1) to analyze the demand 
and participation for UCE, as compared to other CE providers; and (2) to describe participant profiles in terms of gender, age, family obligations, and job situations. We argue that demand for continuing education and training is primarily controlled by labour-market demand and that many welleducated individuals adopt continuing education strategies to increase their employment and career chances. At the same time, we anticipate that social structures and life-course circumstances (e.g., marriage and parenthood) influence graduates' choice to further their education.

\section{Literature ReView}

There is a clear connection between the effort to provide more education and training opportunities for workers and the changing demands for knowledge and skills that characterize labour markets (Brown, Green, \& Lauder, 2001). Jobs are no longer defined by steady working conditions and skill (competence) requirements. Following the pace of a changing economy, job requirements are becoming more dynamic and require frequent updating, adaptation, and learning (Rubenson \& Schuetze, 2000). In this context, $\mathrm{CE}$ has become increasingly significant for individuals' employability and success in the labour market. To continue learning beyond an initial postsecondary education from a technical school, college, or university is an important part of lifelong learning. Many scholars view lifelong learning as the main instrument of knowledge-based economies, which explains the increased support for and proliferation of lifelong learning (Schuetze \& Casey, 2006).

Demand for and participation in continuing education can be discussed from different perspectives. One perspective focuses on the institution (the supply side), that is, CE's organization and finance, programs and marketing, and development in terms of the number of overall participants, programs, mode of study, etc. Another perspective analyzes CE from an epistemological venture point, trying to determine what is (or should be) offered and learned in initial education and what must (or can better) be learned at a later point in a learner's life. Still another perspective concentrates on the participants (the demand side), that is, their characteristics and their reasons for engaging in or disengaging from CE initiatives. Universities continue to be major settings where, to use economic terminology, human capital is created and upgraded, and UCE plays a significant role in that process. Furthermore, as universities in many countries accept the challenge of lifelong learning, that acceptance is facilitated by the fact that UCE is an important source of revenue (Schuetze \& Slowey, 2002).

Most studies on UCE concentrate on the institutional side, rather than on participants and their reasons for and patterns of participation. That applies 
also to Canada, where the majority of studies have examined institutional issues or aspects of the educational services offered by UCE units (McLean, 2007; Thompson \& Archer, 2003); the last comprehensive study on UCE in Canada is 15 years old (Brooke \& Waldron, 1994). A survey series on UCE conducted by Statistics Canada in the 1990s was discontinued because of uneven reporting by universities and little demand, other than from universities, for these data among the research community. Although institutional data on UCE provide useful information on participant numbers, program offerings, and organizational issues, it is the patterns and conditions of participation that are essential in understanding the demand for UCE. Both the Adult Education and Training Survey (AETS) and the National Graduates Survey (NGS) contain data not just on CE participation in general but also on how universities respond to learners' needs, what barriers are experienced by graduates, and to what extent UCE is seen as a viable component of lifelong learning.

Cross (1981) proposed a life-course framework that distinguishes individual, situational, and dispositional categories that describe incentives and barriers to educational participation and choice for adults. Individual factors are usually demographic and characterize personal status (e.g., gender, age, immigrant status); situational factors describe life circumstances that favour or hinder participation (e.g., marital status, dependent children, availability of resources such as financial support or employment); and dispositional factors are predispositions and perceptions that influence an individual's decision to participate (e.g., self-esteem, educational aspirations). In addition to these categories, there are institutional factors that enhance or, conversely, negatively affect participation, such as the type of program or course, its duration, the type of instruction employed, and the availability of part-time and distance studies (see, e.g., Schuetze \& Slowey, 2002). These factors are relevant in models that describe institutional choices.

Cross's Chain-of-Response (COR) opportunity structures typology is quite flexible and has been the basis of many studies on the participation decision in adult education (see, e.g., Adamuti-Trache \& Sweet, 2008; Rubenson, 2001; Sweet, Adamuti-Trache, \& Anisef, 2005). Although a multivariate analysis of CE participation is beyond the scope of the current study, Cross's typology is employed to identify personal attributes, work and family situations, and dispositional factors that differentiate participation by male and female university graduates in various forms of CE.

\section{METHOD}

Data on CE participation by the 1995 cohort of university graduates in relation to their personal attributes and work and family characteristics have 
been analyzed. The study focused on the institutions where graduates took part in continuing education and on the role of UCE in their decision to participate. By analyzing the profiles of UCE participants (i.e., gender, age, employment situation) and contrasting their profiles against those who chose not to participate as well as those who engaged in non-university continuing education (NUCE), the study authors sought to determine the demand potential for UCE and identify barriers to and incentives for participation.

\section{Data and Research Sample}

This paper employed data from the 1995 National Graduates Survey (NGS) administered by Statistics Canada. The survey contains information on graduates of Canadian post-secondary institutions obtained from interviews conducted two and five years after graduation, that is, in 1997 and in $2000 .{ }^{2}$ In particular, the NGS draws from a large population of university graduates and it provides micro data on respondents' demographic characteristics, family obligations, current employment and occupational status, and participation in continuing education. The longitudinal NGS database that assembles the 1997 and 2000 data provides valuable insights into the lifelong learning aspect of continuing education. However, for the purpose of this study, participation in CE was measured by formal education events that occurred any time within five years after university graduation.

The study sample consisted of respondents who completed a bachelor's or first professional degree and who held no other previous degree before engaging in the program completed in 1995. The full population satisfying these two requirements corresponded to 97,250 graduates. There was a clear dominance of traditional-age students $-71 \%$ were 24 years or younger at the time of graduation, while $22 \%$ were between the age of 25 and 34 , and $5 \%$ and $2 \%$ were in the 35 to 44 and the above- 45 age range, respectively. The gender distribution was uneven, $39 \%$ male and $61 \%$ female, which reflects the characteristics of the 1995 university graduate population. Data were analyzed by applying survey weights; thus, the results were representative of the graduate population.

\section{Variables}

Continuing education participation was defined by enrolment in at least one educational event (i.e., program or course) at the post-secondary level within five years of graduating from university and was differentiated by institution type, as university (UCE) versus non-university (NUCE). UCE participation was further differentiated by the purpose of the program/course, that is, second degree (SD) and non-degree (ND). Since some respondents had engaged in more than one CE activity (e.g., took both a non-degree 
university program and a course at another non-university institution such as a private training institute), multiple responses were acceptable.

Respondents often indicated multiple reasons for participating in each continuing education program or course. These reasons were classified into two major categories: those related to jobs or further education (e.g., get or keep a job; get a better job or better pay; prerequisite for further education; part of a degree, diploma, certificate) and those related to general interest (e.g., personal interest and self-development). The single two-category variable that was computed to describe either job/education-related or general reasons gave priority to the former category if at least one job/educationrelated reason was reported in relation to an educational activity.

Several correlates of participation were proposed, based on Cross's (1981) model of participation in adult education: demographic factors (i.e., gender, age at graduation); situational factors - family responsibilities (i.e., marital status, parenthood); situational factors-employment characteristics (i.e., employment status, job type and job permanency, job-related reasons for $\mathrm{CE}$ ); and dispositional factors - perception of job situation (i.e., relationship between job and education, feeling of overqualification, job and income satisfaction). Employment, job, and family data were based on the 2000 interviews, five years after graduation.

\section{FINDINGS}

In this section, data on CE participation and non-participation and on the choice of university continuing education (either to obtain a second degree or pursue non-degree education) or non-university education are presented and discussed (Tables 1a and 1b). Then, we examine the influence of family obligations on participation and institutional and program choice (Tables $2 \mathrm{a}$ and $2 \mathrm{~b}$ ). Finally, we demonstrate that employment status and job characteristics (Tables 3a and 3b), as well as graduates' perceptions of their job situation and the link between job and education (Tables $4 a$ and $4 b$ ) have a bearing on participation.

\section{Participation in Continuing Education}

The total cohort consisted of 97,250 graduates, of whom about one-third were more than 25 years of age at the time of graduation (Table 1a). More than two-thirds (68\%) of the graduates under 25 had engaged in some organized CE activity offered by post-secondary institutions. This participation rate was higher than the participation rate of older graduates (56\%). This somewhat surprising difference likely occurred because the older graduates presumably had some prior work-related training and experience that gave them some of the "extra-curricular competences" often looked for by 
employers (Maslove, Fischer, \& O'Heron, 1998). There was almost no difference in participation rates between male and female participants in the younger group; by contrast, men in the older group were much more active in CE than women (61\% vs 53\%). Again, this may seem somewhat odd given that women outnumber men in almost all other educational activities; however, family obligations may provide at least part of the explanation for why respondents participated in CE (or not) beyond obtaining a first degree, within the first five years of graduation.

Table 1a: CE participation by age and gender ( $\%$ of $\left.N_{\text {total }}\right)$

\begin{tabular}{|c|c|c|c|c|c|c|}
\hline & \multirow{2}{*}{$\begin{array}{c}\text { All } \\
\text { graduates } \\
\mathbf{N}_{\text {total }}\end{array}$} & \multicolumn{2}{|c|}{ Non-Participants } & \multicolumn{2}{|c|}{ Participants } \\
\hline & & & $\mathbf{N}$ & $\%$ & $\mathbf{N}$ & $\%$ \\
\hline \multirow{3}{*}{ 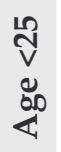 } & All & 68,910 & 22,200 & 32 & 46,710 & 68 \\
\hline & Male & 26,930 & 8,350 & 31 & 18,580 & 69 \\
\hline & Female & 41,980 & 13,850 & 33 & 28,130 & 67 \\
\hline \multirow{3}{*}{ 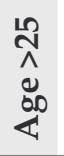 } & All & 28,340 & 12,430 & 44 & 15,910 & 56 \\
\hline & Male & 11,170 & 4,360 & 39 & 6,810 & 61 \\
\hline & Female & 17,170 & 8,070 & 47 & 9,100 & 53 \\
\hline
\end{tabular}

Table $1 \mathrm{~b}$ presents the distribution of participants across different institutions (universities vs. non-university) and, for those attending university, between different programs (degree vs. non-degree). Since graduates enrolled in more than one institution or form of continuing education, the number of participants and the corresponding percentages of the total number of graduates in each age-gender group are reported. In other words, we have disentangled the information by showing the participation in both UCE (university CE) and NUCE (non-university CE) and by separating UCE participation into UCE_SD (second degree) and UCE_ND (non-degree). ${ }^{3}$ For instance, Table $1 \mathrm{~b}$ shows that $49 \%$ of all graduates under 25 years of age enrolled in UCE and 33\% enrolled in NUCE; for the older graduates, the corresponding percentages are $38 \%$ and $28 \%$, respectively.

The overall participation in UCE was sizeable, with larger proportions of graduates enrolled in second-degree programs and for-credit courses that could be counted toward a degree. Differences between male and female participation rates were minimal, but differences between younger and older graduates were more significant. Second-degree participation remained quite high, even for the least-represented group of women above 25 years of age $(23 \%)$. In contrast, non-degree programs offered by universities were in slightly less demand for all graduates, ranging between $17 \%$ for the older group and $23 \%$ for the younger group. 


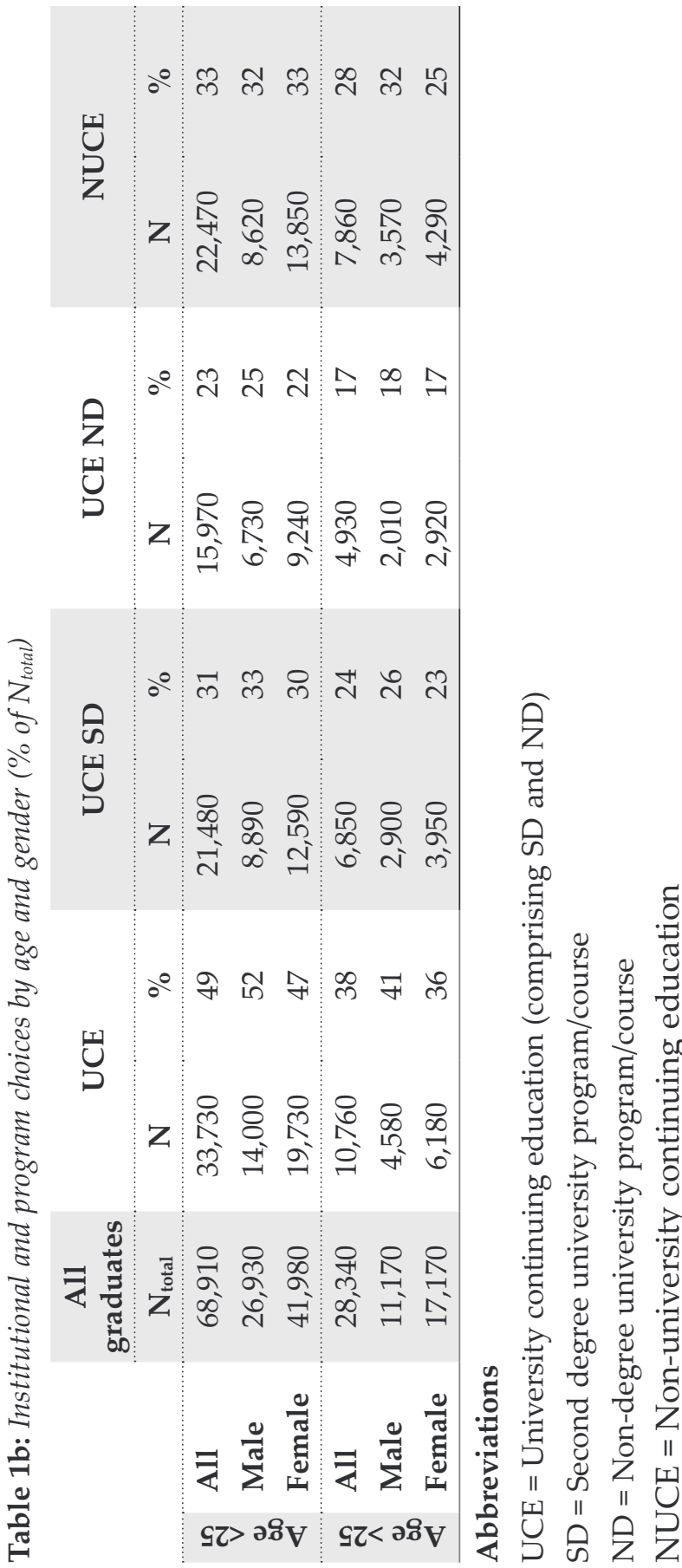

Canadian Journal of University Continuing Education Vol. 35, No. 2, fall 2009 
The large participation in non-university CE-33\% of younger graduates and $28 \%$ of older graduates - was remarkable. The bulk of these participants were likely enrolled in courses and programs that offered more practical and job-specific know-how. This seems to be a growing trend, as evidenced by the substantial number of university graduates with a first degree who had enrolled in courses and programs in community colleges and technical institutes to learn additional employment-relevant skills. It is unclear, however, why participation in non-university $\mathrm{CE}$ by women 25 years and older was notably lower, compared to their male counterparts.

\section{Family Situational Factors}

Family responsibilities are still an impediment to participation in continuing education by adults. As shown in Table 2a, for both women and men, larger proportions of non-participants than participants were married and had dependent children. However, these percentages varied strongly by gender: $38 \%$ of female respondents who did not participate in CE had children, as compared to $23 \%$ of the male respondents.

Table 2a: Family obligations and CE participation by gender

\begin{tabular}{|c|c|c|c|c|c|c|}
\hline & \multicolumn{2}{|c|}{ All graduates } & \multicolumn{2}{|c|}{ Non-participants } & \multicolumn{2}{|c|}{ Participants } \\
\hline & 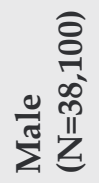 & 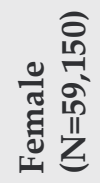 & 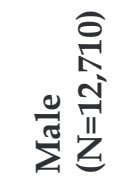 & 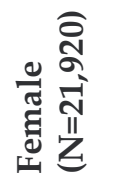 & 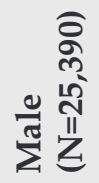 & 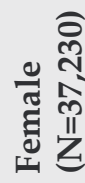 \\
\hline & $\%$ & $\%$ & $\%$ & $\%$ & $\%$ & $\%$ \\
\hline Married & 48 & 57 & 53 & 63 & 46 & 53 \\
\hline $\begin{array}{l}\text { Dependent } \\
\text { children }\end{array}$ & 21 & 28 & 23 & 38 & 20 & 23 \\
\hline
\end{tabular}

Table $2 \mathrm{~b}$ provides more detail about the impact of family obligations on institutional and program choices for CE participants. Differences between UCE and NUCE were more pronounced for men than for women; whereas $25 \%$ of NUCE male and female participants had dependent children, only $15 \%$ of men and $18 \%$ of women in SD university programs were parents. For both women and men, higher proportions of respondents who were married and had children were found among NUCE participants, compared to ND and SD participants. 
Table 2b: Family obligations and institutional and program choices by gender

\begin{tabular}{|c|c|c|c|c|c|c|c|c|}
\hline & \multicolumn{2}{|c|}{ UCE } & \multicolumn{2}{|c|}{ UCE SD } & \multicolumn{2}{|c|}{ UCE ND } & \multicolumn{2}{|c|}{ NUCE } \\
\hline & 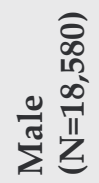 & 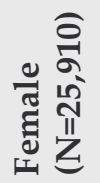 & 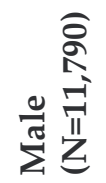 & 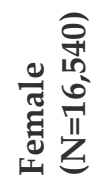 & 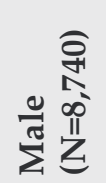 & 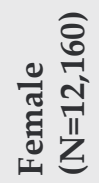 & 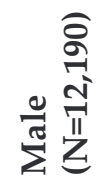 & 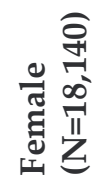 \\
\hline & $\%$ & $\%$ & $\%$ & $\%$ & $\%$ & $\%$ & $\%$ & $\%$ \\
\hline Married & 44 & 52 & 42 & 50 & 45 & 54 & 51 & 54 \\
\hline $\begin{array}{l}\text { Dependent } \\
\text { children }\end{array}$ & 16 & 21 & 15 & 18 & 17 & 24 & 25 & 25 \\
\hline
\end{tabular}

\section{Employment Situational Factors}

The fact that the Canadian labour market is gendered is well documented (see, e.g., Fortin \& Huberman, 2002; Shannon \& Kidd, 2001); this fact is also reflected in the NGS data. Several employment measures that support the argument that women are not equitably treated in terms of employment and jobs are discussed next.

The tables in this section do not include the total number of graduates who participated across the various CE categories, because the number of graduates who responded to different survey questions varied. Instead, for each job characteristic, the actual number and the percentage of the total (unreported) valid responses it represented are provided. For instance, according to Table 3a, 34,890 men were employed in 2000 and they represented $92 \%$ of all the men who gave valid responses regarding employment; of that total number of employed men, 12,040 represented $95 \%$ of the male non-participants and 22,850 represented $90 \%$ of the male CE participants. Based on these statistics, employment was slightly higher among nonparticipants.

Table 3a also illustrates that fewer female graduates were employed in a full-time, permanent job. Therefore, it is not surprising that of the women who participated in CE, $85 \%$ did so for job-related reasons, a slightly higher percentage than that for men. There was strong evidence that the great majority of participants, both men and women, continued learning for joband career-related reasons, a phenomenon found in other surveys, such as the Adult Education and Training Survey (Peters, 2004; Rubenson, 2001). 
Table 3a: Employment profiles and CE participation by gender

\begin{tabular}{|c|c|c|c|c|c|c|c|}
\hline & & \multicolumn{2}{|c|}{ All graduates } & \multicolumn{2}{|c|}{$\begin{array}{c}\text { Non- } \\
\text { Participants }\end{array}$} & \multicolumn{2}{|c|}{ Participant } \\
\hline & & $\mathbf{N}$ & $\%$ & $\mathbf{N}$ & $\%$ & $\mathbf{N}$ & $\%$ \\
\hline \multirow{2}{*}{ Employed } & Male & 34,890 & 92 & 12,040 & 95 & 22,850 & 90 \\
\hline & Female & 52,650 & 89 & 19,770 & 90 & 32,880 & 88 \\
\hline \multirow{2}{*}{$\begin{array}{l}\text { Full-time } \\
\text { job }\end{array}$} & Male & 33,140 & 95 & 11,600 & 96 & 21,540 & 94 \\
\hline & Female & 46,030 & 87 & 17,400 & 87 & 28,630 & 87 \\
\hline \multirow{2}{*}{$\begin{array}{l}\text { Permanent } \\
\text { job }\end{array}$} & Male & 27,850 & 89 & 9,440 & 90 & 18,410 & 89 \\
\hline & Female & 42,200 & 86 & 16,280 & 89 & 25,920 & 84 \\
\hline \multirow{2}{*}{$\begin{array}{l}\text { Job-related } \\
\text { reasons } \\
\text { for CE }\end{array}$} & Male & NA & NA & NA & NA & 20,960 & 83 \\
\hline & Female & NA & NA & NA & NA & 31,510 & 85 \\
\hline
\end{tabular}

Although some data provided clear support for the labour market-related reasons for $\mathrm{CE}$ participation, other data were more ambiguous. Thus, the difference between participants and non-participants in CE with regard to employment and to full-time and permanent employment status, although relatively small, was noteworthy. Whereas $95 \%$ of male non-participants were employed, only $90 \%$ of male CE participants were in this category (the corresponding numbers were $90 \%$ for female non-participants and $88 \%$ for participants). Of the women who did not participate in CE, $89 \%$ had a permanent job; of those who participated, only $84 \%$ held a permanent job. This "gap" in employment status is assumed to be the rationale for participating in continuing education.

Table $3 \mathrm{~b}$ examines the same categories as Table $3 \mathrm{a}$, but differentiates between institutions and programs. While percentages of employed graduates were very similar for women and men enrolled in UCE, they were lower for women participating in NUCE. Gender differences in job permanency and full-time work were visible within all continuing education categories.

Generally, the analysis of the motivation to participate in continuing education demonstrated the overwhelming influence of job-related reasons. As indicated in Table 3a, when asked whether at least one educational activity was pursued for reasons related to increasing job and career opportunities, $83 \%$ of male and $85 \%$ of female CE participants gave a positive response. However, Table $3 \mathrm{~b}$ shows some variation across the CE sectors: involvement of men who declared job-related goals ranged from $81 \%$ (SD) to $90 \%$ (ND). Women enrolled in UCE were the most likely to do so for job-related purposes (88\%), regardless of the type of activity (SD or ND), while men 
enrolled in UCE were more likely to participate in ND activities for this purpose $(90 \%)$, compared to SD activities $(81 \%)$.

Table 3b: Employment profiles and institutional and program choices by gender

\begin{tabular}{|c|c|c|c|c|c|c|c|c|c|}
\hline & \multicolumn{2}{|c|}{ UCE } & \multicolumn{2}{|c|}{ UCE_SD } & \multicolumn{2}{|c|}{ UCE_ND } & \multicolumn{2}{|c|}{ NUCE } \\
\hline & & $\mathbf{N}$ & $\%$ & $\mathbf{N}$ & $\%$ & $\mathbf{N}$ & $\%$ & $\mathbf{N}$ & $\%$ \\
\hline \multirow{2}{*}{ Employed } & & 16,480 & 89 & 9,880 & 85 & 8,120 & 94 & 11,270 & 93 \\
\hline & $\mathrm{Fe}$ & $22, \varepsilon$ & 88 & 13,990 & 85 & 11,210 & 93 & 16,290 & 89 \\
\hline \multirow{2}{*}{$\begin{array}{l}\text { Full-time } \\
\text { job }\end{array}$} & Male & 15,460 & 94 & 9,030 & 91 & 7,930 & 98 & 10,740 & 96 \\
\hline & male & 19,760 & 87 & 11,610 & 84 & 9,900 & 88 & 14,220 & 87 \\
\hline \multirow{2}{*}{$\begin{array}{l}\text { Permanent } \\
\text { job }\end{array}$} & & 12 & 86 & 7 , & 80 & 6,870 & 94 & 9,350 & 92 \\
\hline & Female & 17,780 & 82 & 10,210 & 76 & 9,190 & 88 & 13,370 & 88 \\
\hline \multirow{2}{*}{$\begin{array}{l}\text { Job-related } \\
\text { reasons } \\
\text { for } C E\end{array}$} & Male & 15,550 & 84 & 9,440 & 81 & 7,790 & 90 & 10,340 & 85 \\
\hline & Female & 22,840 & 88 & 14,610 & 89 & 10.640 & 88 & 15,210 & 84 \\
\hline
\end{tabular}

\section{Graduates' Perception of Job Situation}

Table $4 \mathrm{a}$ and Table $4 \mathrm{~b}$ highlight several measures of graduates' perceptions of their job situation and how it related to education. ${ }^{4}$ These more subjective measures may be a reflection of objective employment situations. For instance, Table 4a shows that more women than men felt overqualified for their job (27\% vs. $22 \%)$ and that fewer women were satisfied with their job and income, a finding that can be associated with the more precarious employment situation of women.

Table 4a also shows that the most notable difference between participants and non-participants was in terms of their perceived relationship between job and education. Only $44 \%$ of male participants and $43 \%$ of female participants believed that their education and job were closely related, compared to $50 \%$ of male non-participants and $51 \%$ of female non-participants. Although overqualification was slightly more pronounced for non-participants, there were practically no differences in terms of job and income satisfaction. 
Table 4a: Perception of job situation and CE participation by gender

\begin{tabular}{l|l|c|c|c|c|c|c|c|} 
& & \multicolumn{3}{c}{ All graduates } & \multicolumn{2}{c}{$\begin{array}{c}\text { Non- } \\
\text { Participants }\end{array}$} & \multicolumn{2}{c|}{ Participants } \\
\hline & & N & $\%$ & N & $\%$ & N & $\%$ \\
\hline $\begin{array}{l}\text { Feel } \\
\text { overqualified }\end{array}$ & Fale & 6,810 & 22 & 2,420 & 23 & 4,390 & 21 \\
\hline $\begin{array}{l}\text { Believe } \\
\text { that job \& }\end{array}$ & Male & 13,070 & 27 & 5,320 & 29 & 7,750 & 25 \\
\hline $\begin{array}{l}\text { education are } \\
\text { closely related }\end{array}$ & Female & 22,760 & 46 & 9,380 & 51 & 13,380 & 43 \\
\hline $\begin{array}{l}\text { Are satisfied } \\
\text { with job }\end{array}$ & Male & 29,630 & 95 & 9,860 & 94 & 19,770 & 95 \\
\hline $\begin{array}{l}\text { Are satisfied } \\
\text { with income }\end{array}$ & Female & 44,640 & 91 & 16,770 & 92 & 27,870 & 90 \\
\hline
\end{tabular}

In general, larger proportions of women felt overqualified for their current job. According to Table $4 \mathrm{~b}$, strong gender differences existed in the association of overqualification with participation in ND: 29\% of female participants but only $19 \%$ of male participants were likely engaged in programs and courses to explore new career options. Women enrolled in UCE (either SD or ND) were in general less likely than men to believe that their job and education were closely related, although this finding was reversed for NUCE participants, where only $37 \%$ of the men participating in NUCE believed job and education were closely related.

This brief discussion illustrates that the graduates' demand for formal continuing education and training appeared to be related to individual goals to maximize chances to succeed in the labour market. As noted in Table 1b, the role of UCE in supporting this goal was comparable to that fulfilled by other post-secondary institutions, although NUCE participation was lower than UCE participation. However, for a sample consisting of baccalaureate graduates, the fact that about one third of them took part in CE activities in non-university institutions (up to $85 \%$ of them doing so for job-related reasons) within five years of university graduation raises questions about the relevance and efficiency of university undergraduate instruction in preparing graduates to immediately integrate into the labour force. This general statement requires further investigation, for example, by looking into the participation levels of graduates from different fields of study (AdamutiTrache, Hawkey, Schuetze, \& Glickman, 2006). It is clear, however, that employability and labour-market success are significant factors in CE participation, even if the relationship is not always straightforward or linear. 

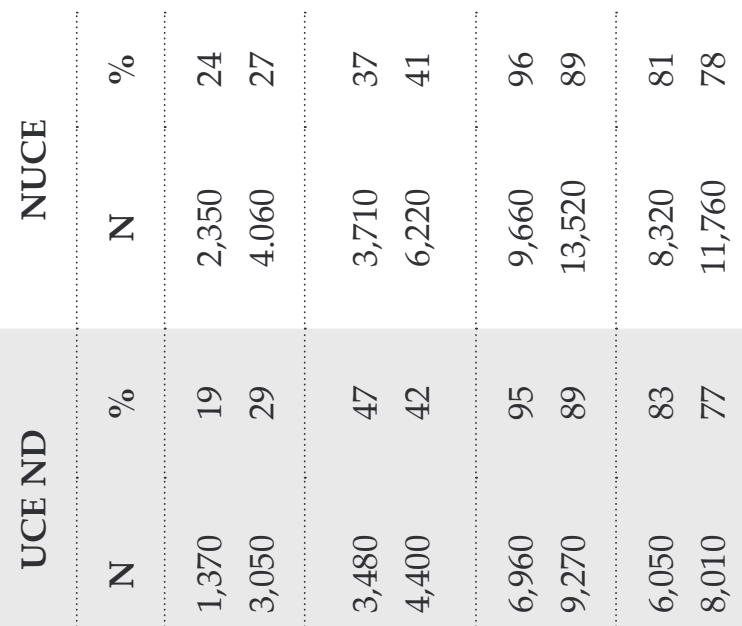

$\frac{\sqrt{2}}{\frac{5}{2}}$

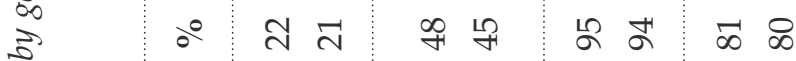

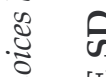

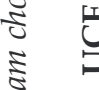

क

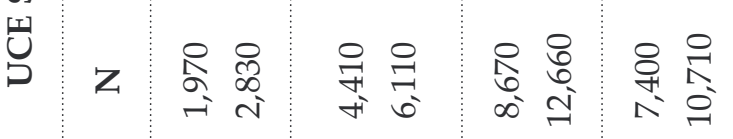

$\frac{1}{2}$

咅

০ং 유

留
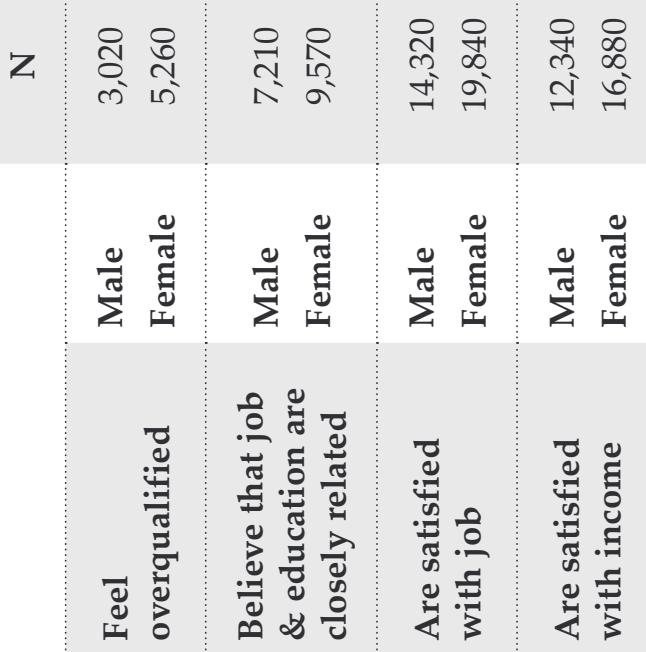

Canadian Journal of University Continuing Education

Vol. 35, No. 2, fall 2009 


\section{Summary and Conclusion}

What, then, does emerge from the NGS data with regard to the questions we asked at the beginning of this article? First, although quite useful for UCE analysts and institutional planners, and for programming and marketing purposes, the NGS data do not provide a full picture of the demand for and participation in university continuing education. Nonetheless, a number of relevant conclusions can be drawn from the NGS data with respect to our questions.

\section{Demand and Participation}

Although potential demand for continuing education is by definition greater than expressed demand, participation data were actually much more reliable than data from more-general demand surveys, especially when they were broken down, as was the case with the NGS, by personal characteristics of the participants. Overall, of the 1995 cohort, more than two-thirds $(68 \%)$ of the under-25-year-olds and more than half (56\%) of those aged 25 and over had participated in at least one CE activity within five years of graduation. This is a clear indication that lifelong learning is no longer a utopian and elusive concept but rather a reality for the majority of the workforce, at least the qualified segment of it.

Most of the participants went back to university, the larger share into second-degree programs, the smaller share into non-degree programs. A minority took their continuing education at non-university institutions such as colleges, institutes, or specialized training institutions. This comparison is somewhat skewed, however, since non-university institutions cannot offer degree programs. When just the number of participants enrolled in university second-degree programs or non-degree programs and courses was compared with those going to non-university institutions for $\mathrm{CE}$, non-university $\mathrm{CE}$ appeared to be in greater demand than university-based programs. This seems to be a growing trend; indeed, several studies have shown that a substantial number of university graduates with a first degree enrol in courses and programs in community colleges and technical institutes to learn additional employment-relevant skills (Walters, 2003).

These numbers can be interpreted in several ways. One interpretation is that second-degree studies are not really "continuing" but part of the initial education ladder, since a second, often advanced, degree is the prerequisite for a number of qualified jobs. For example, in many jurisdictions, a bachelor of education degree is a prerequisite for gaining accreditation as a teacher and a bachelor of laws is required to become a member of the Bar. Another interpretation suggests that because undergraduate education, especially liberal arts programs, does not sufficiently prepare students for 
the realities of the workplace, graduates must pick up more workplace-relevant skills and know-how to satisfy employers' demands. As most UCE programs do not offer workplace-relevant courses, graduates turn to colleges, institutes, or specialized training institutions to acquire the additional skills they need to be more successful in the labour market.

\section{Participant Profiles and CE Motivation}

The study data have shown that family and jobs continue to have "long arms," which influence CE participation, and that individual factors like age and gender are also related to family and jobs. Table 1a indicates that more men than women participated in continuing education, and this was true for all three types of programs distinguished here. The exception, illustrated in Table $1 b$, was the slight domination of younger women in NUCE, an indication of the difficulty young women have in finding a job without additional job-relevant education. The overrepresentation of men in CE activities was somewhat surprising, given the general trend for proportionally more women than men to go to university.

In both age categories (below and above 25 years), women participated less than men, a finding that highlights two factors that may determine participation: family responsibilities and employment status. At the same time, family responsibilities and having dependent children no longer seem to be barriers to continuing education for women. As shown in Table 2a, more married women, and more women with dependent children, than men were found among CE participants. Nonetheless, it is difficult to conclude from the data whether the long arm of the family has become shorter for women or whether the specific difficulties women encounter in a gendered labour market are the main driver of this development. A number of factors indicate the latter. Among the CE participants, more women than men cited job-related reasons for enrolling in CE (Table 3a), more women than men felt overqualified for their present job, and fewer women than men were satisfied with their job and income (Table 4a).

The respondents' labour-market situation, both in objective and subjective terms, was an important determinant of participation in all CE categories. This should not be surprising for the young adults, since the data in this study only covered the first five years after graduation, a time when finding a satisfactory job with promising career prospects is the major preoccupation of young people starting their working life. Family obligations, although essential, are of secondary importance. Having to care for dependent children did not seem to be a major obstacle to participation, although this finding might have been quite different had we looked at data for single parents.

Overall, our study provides a snapshot of participant profiles in relation to work and family for one particular group of well-qualified people, who 
had completed a first bachelor's degree. Particularly significant findings were that less than $50 \%$ of university graduates worked in jobs that were closely related to their education and that over $80 \%$ of those who engaged in continuing education and training reported job- and education-related motives for doing so. These findings suggest that these individuals were in search of better employment and/or career development or change. The essential challenge for UCE planners is to analyze their programs, especially the non-degree offerings, in light of the demand from this group.

\section{Disclaimer}

The analyses in this article were based on data from Statistics Canada. The opinions and interpretation expressed by the authors do not represent the views of Statistics Canada.

\section{ENDNOTES}

1. The OECD differentiates between "formal" education (i.e., follows a structured ladder system; takes place in schools, colleges, universities, and other educational institutions; and mainly caters to young learners) and "non-formal" education (i.e., organized learning that takes place outside educational institutions and is addressed to all ages). University continuing education is a hybrid: it is formal since it takes place in universities and non-formal since it is not always part of a consecutive laddering system.

2. More-recent NGS surveys were administered to a cohort of graduates who completed their studies in 2000. The information on continuing education is less comprehensive (e.g., mainly program participation), which makes the NGS 1995 database particularly interesting. More information can be found on the Statistics Canada (2003) website.

3. In both cases, numbers do not add up due to graduates being engaged in more than one educational activity.

4. Similar to Tables $3 \mathrm{a}$ and $3 \mathrm{~b}$, Tables $4 \mathrm{a}$ and $4 \mathrm{~b}$ do not include the total number of graduates who participated across the various CE categories because the number of graduates who responded to different survey questions varied. Instead, for each measure of graduates' perception of job situation, the actual number and the percentage of the total (unreported) valid responses it represented are provided. 


\section{REFERENCES}

Adamuti-Trache, M. (2008). Further education pathways of Canadian university graduates. Journal of Adult and Continuing Education, 14(2), 147-167.

Adamuti-Trache, M., Hawkey, C., Schuetze, H. G., \& Glickman, V. (2006). The labour market value of liberal arts and applied education programs: Evidence from British Columbia. Canadian Journal of Higher Education, 36(2), 49-75.

Adamuti-Trache, M., \& Sweet, R. (2008). Vocational training choices of women: Public and private colleges. Gender and Education, 20(2), 167-182.

Bélanger, P., \& Tuijnman, A. (Eds.). (1997). New patterns of adult learning: A six country comparative study (1st ed.). Oxford: Pergamon \& UNESCO Institute for Education.

Brooke, W. M., \& Waldron, M. (Eds.). (1994). University continuing education in Canada: Current challenges and future opportunities. Toronto: Thompson Educational Publishing.

Brown, P., Green, A., \& Lauder, H. (Eds.). (2001). High skills: Globalization, competitiveness, and skill formation. Oxford, UK: Oxford University Press.

Cross, P. (1981). Adults as learners. San Francisco: Jossey-Bass.

Fortin, N. M., \& Huberman, M. (2002). Occupational gender segregation: Public policies and economic forces. Introduction and overview. Canadian Public Policy, 28(Sup. 1), 1-10.

Maslove, L., Fischer, L., \& O’Heron, H. (1998). Making the transition: No two paths alike. Research File, 2(4), 1-11.

McLean, S. (2007). About us: Expressing the purpose of university continuing education in Canada. Canadian Journal of University Continuing Education, 33(2), 65-86.

Myers, K., \& de Broucker, P. (2006). Too many left behind: Canada's adult education and training system. Ottawa, ON: Canadian Policy Research Networks.

Organization for Economic Co-operation and Development. (2008). Education at a glance 2008. Paris: OECD. Retrieved July 9, 2009, from http://www. oecd.org/dataoecd/23/46/41284038.pdf. 
Peters, V. (2004). Working and training: First results of the 2003 Adult Education and Training Survey (Catalogue number 81-595-MIE20040015. Research papers series). Ottawa, ON: Statistics Canada.

Rohfeld, R. W. (Ed). (1990). Expanding access to knowledge: Continuing higher education. Washington, DC: National University Continuing Education Association.

Rubenson, K. (2001). Measuring motivation and barriers in the AETS: A critical review (Report No. R-01-9-2E). Ottawa, ON: Human Resources Development Canada.

Rubenson, K., \& Schuetze, H. G. (2000). Lifelong learning for the knowledge society: Demand, supply, and policy dilemmas. In K. Rubenson \& H. G. Schuetze (Eds.), Transition to the knowledge society: Policies and strategies for individual participation and learning (pp. 355-376). Vancouver: University of British Columbia, Institute for European Studies.

Schuetze, H. G., \& Casey, C. (2006). Models and meanings of lifelong learning: Progress and barriers on the way to the learning society. Compare, 36(3), 279-287.

Schuetze, H. G., \& Slowey, M. (2002). Participation and exclusion: A comparative analysis of non-traditional students and lifelong learners in higher education. Higher Education, 44, 309-327.

Selman, G., Cooke, M., Selman, M., \& Dampier, P. (1998). The foundations of adult education in Canada (2nd ed.). Toronto: Thompson Educational Publishing.

Shannon, M., \& Kidd, M. P. (2001). Projecting the trend in the Canadian gender wage gap 2001-2031: Will an increase in female education acquisition and commitment be enough? Canadian Public Policy, 27(4), 447-467.

Statistics Canada. (2003). National Graduates Survey (NGS). Retrieved July 20, 2009, from http://www.statcan.gc.ca/cgi-bin/imdb/p2SV.pl?Function=ge tSurvey\&SurvId=20168\&SurvVer=3\&InstaId=15771\&InstaVer=9\&SDDS $=5012 \&$ lang $=$ en $\& \mathrm{db}=\mathrm{imdb} \& \mathrm{adm}=8 \&$ dis $=2$.

Sweet, R., Adamuti-Trache, M., \& Anisef, P. (2005). Vocational training for women: Public and private options. Toronto: York University, Centre for Research on Work and Society.

Thompson, G., \& Archer, W. (2003). A survey of the professional development needs and interests of CAUCE members. Canadian Journal of University Continuing Education, 29(2), 73-84. 
Titmus, C., Knoll, J. K., \& Wittpoth, J. (1993). Continuing education in higher education: Academic self-concept and public policy in three European countries. Leeds, UK: Leeds Studies in Continuing Education.

Walters, D. (2003). Recycling: The economic implications of obtaining additional postsecondary credentials at lower or equivalent levels. Canadian Review of Sociology and Anthropology, 40(4), 463-480. 


\section{BIOGRAPHIES}

Maria Adamuti-Trache has a doctoral degree in physics from the University of Bucharest (Romania), where she taught theoretical physics for 15 years. She received an MA in Higher Education from the University of British Columbia and is currently completing a PhD in Educational Studies at UBC, where she is a research manager and statistical consultant in the Faculty of Education. Her expertise is in life-course research, which explores the impact of gender, age, social class, ethnicity, and immigrant status on education and work transitions.

Maria Adamuti-Trache détient un doctorat en physique de l'Université de Bucarest (en Roumanie), ou elle a enseigné la physique théorique pendant 15 ans. Elle a obtenu une maîtrise en éducation supérieure de l'Université de la Colombie-Britannique et termine actuellement un doctorat d'études en éducation à l'Université de la Colombie-Britannique, où elle travaille à titre de gestionnaire des recherches et consultante en statistique à la Faculté de l'éducation. Son expertise est en recherche sur le parcours de vie, qui explore l'impact du sexe, de l'âge, de la classe sociale, de l'ethnicité et du statut immigrant sur l'éducation et les transitions d'emploi.

Hans G. Schuetze studied social sciences, economics, and law at the universities of Göttingen and Bonn (Germany), Grenoble (France), and California at Berkeley (United States). From 1991 to 2005, he was a professor of Higher Education in the University of British Columbia's Department of Educational Studies and a senior fellow and former director of the Centre for Policy Studies in Higher Education and Training. Professor emeritus since 2006, he continues to be involved in discussions about higher education and lifelong learning. He has also joined a law practice, where he specializes in legal issues in education and in international human rights issues.

Hans G. Schuetze a étudié en sciences sociales, en science économique et en droit aux universités de Göttingen et Bonn (en Allemagne), de Grenoble (en France), et de la Californie à Berkeley (aux États-Unis). De 1991 à 2005, il était professeur de l'éducation supérieure au département d'études en éducation de l'Université de la Colombie-Britannique, agrégé supérieur de recherches et ancien directeur du Centre d'études politiques en éducation supérieure et en formation. Professeur émérite depuis 2006, il continue à s'impliquer dans des discussions sur l'éducation supérieure et l'éducation permanente. Il s'est aussi joint à un cabinet d'avocats, où sa spécialité concerne des questions juridiques en éducation et sur les droits de la personne à l'échelle internationale. 